\title{
The Impact of Teachers' Belief on EFL Writing Instruction
}

\author{
Bita Khanalizadeh \\ Islamic Azad University, Najafabad Branch, Iran \\ Email: bkhanalizadeh@yahoo.com \\ Hamid Allami \\ Yazd University, Iran \\ Email: hamid_allami@yahoo.com
}

\begin{abstract}
This study examines Iranian EFL teachers' beliefs about writing instruction. A sample of 122 EFL teachers teaching at private language institutes were randomly selected, consisting of EFL teachers with different degrees of educational qualification, years of experience, and genders. Questionnaires were submitted to the participants and then analyzed to determine whether the participants hold a form-based, a processbased, or a social-based view of writing. The responses were then compared in terms of their level of education, experience, and gender. Results suggest that most of the teachers were eclectic in their orientations, but the form-based view was the dominant one. Also Chi-square analyses indicate that teachers' orientations to teaching writing were not affected by the level of education or year of experience or gender.
\end{abstract}

Index Terms - cognition, belief, EFL, writing

\section{INTRODUCTION}

Researchers in the past 40 years have studied teachers' cognition and have considered the study of teachers' belief about teaching, learning, learners, and the influence it may have on teaching practices, activities, and learning outcomes (Burns, 1992; Shavelson, \& Stern, 1981) to find effective teaching behaviors.

In the 1980s the study of different aspects of teachers' cognition became an important area of research. Educational researchers thus became more aware of the fact that teachers' mental lives played a role in their instructional choices (Elbaz, 1981; Shulman, 1987) so the main focus was on studying the way teachers think about their work, their mental processes in planning their teaching, their decisions, and their beliefs. How teachers construct their conceptions and theories about teaching (Connelly \& Clandinin, 1988; Leinhardt, 1990), teachers' understanding of the teaching processes (Peterson \& Comeaux, 1987), teachers' belief about teaching, students, teachers, and the learning processes (Hollingsworth, 1989; Kagan \& Tippins, 1991), and the instructional thoughts, actions, and decision making in the classroom (Fogarty, Wang \& Creek, 1983; Magliaro \& Borko, 1986) are amongst the subject matters that have been examined in this respect.

Teacher's belief is a complicated phenomenon that involves various aspects. Beliefs might be defined as one's personal views, conceptions, and/or theories (Thompson, 1992). According to Pajares (1992), belief systems represent a personal guide by helping individuals define and understand the world and themselves. Teachers' beliefs play a central role in the process of teacher development because teachers are highly influenced by their beliefs, which in turn are closely linked to their values, to their views of the world and to their conceptions of their place within it (Williams\&Burdrn, 1997).

One of the aspects of teachers' cognition in language teaching is teachers' beliefs, knowledge, and thinking about writing skills and its teaching. Teaching writing skills is one of the most difficult aspects of teaching English, because it remains unclear how students acquire the skills needed to produce an effective piece of writing in another language. Compared to other language skills it seems that less priority is given to writing skill. There has been a lot debate about how to teach writing skill and what activities should be practiced in the classrooms. No studies have focused exclusively on foreign English language teachers' beliefs about teaching writing. Specifically, this study focuses on the theoretical orientations of writing instruction held by teachers. teachers' beliefs are analyzed according to three major theoretical orientations to writing: writing as a formal system, writing as a cognitive process, and writing as a social activity. These theoretical orientations are described below.

Writing can be seen as a formal system. Theories of writing under this orientation emphasize the linguistic and rhetorical characteristics of a text. Writing, according to this viewpoint, is seen as production of a text which follows the conventions of English rhetoric and proper usage. Teaching writing is typically product-oriented with a focus on correct language and sentence. Two main approaches to teaching writing from this perspective are controlled composition and current traditional rhetoric (Silva, 1990). 
Writing can also be seen as a cognitive process which emphasizes the mental operations that a writer goes through when composing. According to Tribble (1996), process approaches stress "writing activities which move learners from the generation of ideas and the collection of data through to the 'publication' of a finished text" (p.37). Learning to write through the process approach means dealing predominantly with linguistic skills such as planning and drafting and there is much less emphasis on linguistic knowledge, such as knowledge about grammar and text structure.

Writing may also be viewed as a social activity, focusing on the interaction among discourse community members in creating meanings. This approach is based on the assumption that "language is socially constituted" (Gere, 1987, p.87). In this approach, language is seen as embedded in (and constitutive of) social realities since it is through recurrent use of conventionalized forms that individuals develop relationships, establish communities, and get things done. They assume that every successful text will display the writer's awareness of its context.

Learning writing is more difficult than other skills in Iran. It is the least developed language skill and teachers put less time on it as compared to other language skills. Writing skill is often limited to making sentences, and the grammatical points of those sentences are the most important parts of learning how to write well. This could be partly due to the effect of the teachers' beliefs about writing and its teaching. The present study more specifically seeks to answer the following questions:

1- Is there any difference between more experienced and less experienced teachers' beliefs about writing and its teaching?

2- Is there any difference between beliefs of teachers with bachelor degree (BA) and master degree (MA) about writing and its teaching?

3- Is there any difference between beliefs of male and female teachers about writing and its teaching?

4- What are Iranian English language teachers' beliefs about writing and its teaching?

\section{PARTICIPANTS}

This study was conducted with the participation of 122 Iranian EFL teachers teaching at private language institutes in Iran. To be more precise, out of 200 individuals who received the questionnaire sent to four language institutes in Isfahan and an online inquiry through TELLSI (Teaching English Language and Literature Society of Iran) only 122 responded positively. The participants were both female and male (79 female, 43 male) teachers with an age range from 22 to 50. They were all Persian native speakers and their teaching experience varied substantially (from less than a year to 17 years).Based on the years of experience, teachers were divided into three groups. The first group included teachers with less than 2 years of experience. The second included teachers with 2 to 8 years of experience, and the last one included teachers with more than 8years of experience. In addition, their levels of qualification were different; 48 teachers held BA, 74 teachers held MA, and 4 of them were PhD students.

\section{INSTRUMENT}

Following Johnson (1992), a questionnaire was designed consisting of 15 statements about the nature of writing, five related to each of the three orientations described earlier (form-oriented, process-oriented, and social-oriented views). In addition an open-ended question about teachers' overall view of teaching writing skill and its importance was added. The questionnaire was validated by two university lecturers who had been teaching writing for over 16 years. They were asked to group the statements according to the three basic orientations of writing. The reliability of the questionnaire was measured through KR-21 and the correlation coefficient was 0.83 . It was concluded that the newly developed questionnaire was a reliable and valid instrument and could provide us with interpretable data to probe the questions set forth in the study.

\section{PROCEDURE}

Copies of the questionnaire were distributed among teachers in different institutes in Isfahan and to TELLSI members via email. A few teachers answered the items in the questionnaire in their recess times, but most teachers assigned a time for returning the questionnaire, between 3 to 5 days. So the responses were collected during 2 months. Participants were asked to mark 5 statements from the 15 items that most closely reflected their beliefs about how writing in English as a foreign language is learned and how writing in English as a foreign language should be taught, and answer an open-ended question which asked about their beliefs about writing and its importance. In addition the participants were asked to complete 5 demographic questions about their teaching background, experience, and qualifications. Then the collected data was tabulated to be analyzed.

\section{RESULTS}

The participants were classified into three groups based on their teaching experience: 2 years and less (less than one SD below the mean), 2 to 8 yearsbetween (within one SD above and above the mean), and 8 years and over (more than one $\mathrm{SD}$ above the mean). Table 1 shows the descriptive statistics. 
TABLE 1.

THE DESCRIPTIVE STATISTICS OF THE PARTICIPANTS AND THEIR TEACHING EXPERIENCE

\begin{tabular}{|l|l|l|l|l|}
\hline \multirow{4}{*}{ form } & Experience & Mean & Std. Deviation & N \\
\cline { 2 - 5 } & 2 and less & 2.1667 & .64772 & 30 \\
\cline { 2 - 5 } & $2-8$ & 2.1447 & .94804 & 76 \\
\cline { 2 - 5 } & 8 and over & 2.5000 & 1.41421 & 16 \\
\cline { 2 - 5 } & Total & 2.1967 & .95899 & 122 \\
\hline \multirow{5}{*}{ process } & 2 and less & 1.6000 & .89443 & 30 \\
\cline { 2 - 5 } & $2-8$ & 1.6184 & .81596 & 76 \\
\cline { 2 - 5 } & 8 and over & 1.3125 & .79320 & 16 \\
\cline { 2 - 5 } & Total & 1.5738 & .83238 & 122 \\
\cline { 2 - 5 } & 2 and less & 1.2333 & .85836 & 30 \\
\cline { 2 - 5 } & $2-8$ & 1.2500 & .91104 & 16 \\
\cline { 2 - 5 } & 8 and over & 1.1875 & .98107 & 122 \\
\cline { 2 - 5 } & Total & 1.2377 & .90044 & \\
\hline
\end{tabular}

As the table shows, 30 teachers had less than 2 years of teaching experience, 76 had between 2 to 8 years of teaching experience, and only 16 were involved in teaching activities for 8 years and over.

Then a multivariate analysis of variance (MANOVA) was conducted to explore the impact of teaching experience on the participants' responses to the questions of the questionnaire and consequently their approach to teaching writing. Table 2 shows the results.

TABLE 2.

THE RESULTS OF ANALYSIS OF VARIANCE OF THE RESPONSES OF THREE GROUPS BASED ON TEACHING EXPERIENCE

\begin{tabular}{|ll|l|l|l|l|l|}
\hline Effect & & Value & F & Hypothesis df & Error df & Sig. \\
\hline Intercept & Pillai's Trace & 1.000 & $8.259 \mathrm{E} 4$ & 3.000 & 117.000 & .000 \\
& Wilks' Lambda & .000 & $8.259 \mathrm{E} 4$ & 3.000 & 117.000 & .000 \\
& Hotelling's Trace & 2117.610 & $8.259 \mathrm{E} 4$ & 3.000 & 117.000 & .000 \\
& Roy's Largest Root & 2117.610 & $8.259 \mathrm{E} 4$ & 3.000 & 117.000 & .000 \\
\hline Experience & Pillai's Trace & .026 & .524 & 6.000 & 236.000 & .790 \\
& Wilks' Lambda & .974 & $.521^{\mathrm{a}}$ & 6.000 & 234.000 & .792 \\
& Hotelling's Trace & .027 & .519 & 6.000 & 232.000 & .794 \\
& Roy's Largest Root & .024 & $.939^{\mathrm{b}}$ & 3.000 & 118.000 & .424 \\
\hline
\end{tabular}

a. Exact statistic

b. The statistic is an upper bound on $\mathrm{F}$ that yields a lower bound on the significance level.

c. Design: Intercept + Experience

Table 2 reveals that according to all four test statistics of Pillai's Trace, Wilks' Lambda, Hotelling's Trace, and Roy's Largest Root there was not a statistically significant difference at the $p<.05$ level in the responses of the three groups, $\mathrm{F}(6,236)=.524, \mathrm{p}=.790 ; \mathrm{F}(6,234)=.521, \mathrm{p}=.792 ; \mathrm{F}(6,232)=.519, \mathrm{p}=.794 ; \mathrm{F}(3,118)=.939, \mathrm{p}=.424$.

The effect of academic qualification on the approach adopted to teach writing was investigated to find answers to the second research question. Table 3 shows the descriptive statistics.

TABLE 3.

THE DESCRIPTIVE STATISTICS OF THE PARTICIPANTS AND THEIR ACADEMIC QUALIFICATION

\begin{tabular}{|l|l|l|l|l|}
\multicolumn{2}{|l}{ THE DESCRIPTIVE STATISTICS OF THE PARTICIPANTS AND THEIR ACADEMIC QUALIFICATION } \\
\hline \multirow{4}{*}{ Form } & education & Mean & Std. Deviation & N \\
\cline { 2 - 5 } & MA & 2.0946 & .90915 & 74 \\
\cline { 2 - 5 } & BA & 2.3542 & 1.02084 & 48 \\
\cline { 2 - 5 } & Total & 2.1967 & .95899 & 122 \\
\hline \multirow{4}{*}{ process } & MA & 1.5946 & .85878 & 74 \\
\cline { 2 - 5 } & BA & 1.5417 & .79783 & 48 \\
\cline { 2 - 5 } & Total & 1.5738 & .83238 & 122 \\
\hline \multirow{4}{*}{ social } & MA & 1.3243 & .90823 & 74 \\
\cline { 2 - 5 } & BA & 1.1042 & .88100 & 122 \\
\cline { 2 - 5 } & Total & 1.2377 & .90044 & \\
\hline
\end{tabular}

As Table 3 illustrates, 74 teachers held a master's degree and 48 a bachelor's degree.

Similar to the previous section, a MANOVA was run to explore the effect of academic qualification. Table 4 shows the results. 
TABLE 4.

THE RESULTS OF ANALYSIS OF VARIANCE OF THE RESPONSES OF MA AND BA PARTICIPANTS

\begin{tabular}{|ll|l|l|l|l|l|}
\hline Effect & & Value & F & Hypothesis df & Error df & Sig. \\
\hline Intercept & Pillai's Trace & 1.000 & $1.176 \mathrm{E} 5$ & 3.000 & 118.000 & .000 \\
& Wilks' Lambda & .000 & $1.176 \mathrm{E} 5$ & 3.000 & 118.000 & .000 \\
& Hotelling's Trace & 2988.805 & $1.176 \mathrm{E} 5$ & 3.000 & 118.000 & .000 \\
& Roy's Largest Root & 2988.805 & $1.176 \mathrm{E} 5$ & 3.000 & 118.000 & .000 \\
\hline education & Pillai's Trace & .026 & $1.056^{\mathrm{a}}$ & 3.000 & 118.000 & .370 \\
& Wilks' Lambda & .974 & $1.056^{\mathrm{a}}$ & 3.000 & 118.000 & .370 \\
& Hotelling's Trace & .027 & $1.056^{\mathrm{a}}$ & 3.000 & 118.000 & .370 \\
& Roy's Largest Root & .027 & $1.056^{\mathrm{a}}$ & 3.000 & 118.000 & .370 \\
\hline
\end{tabular}

b. Design: Intercept + education

The results of the analysis of variance show no significant difference between the responses of MA and BA participants to the questions of the questionnaire, $\mathrm{F}(3,118)=1.056, \mathrm{p}=.370$.

The teaching approaches adopted by female and male participants were compared and the answer to the third research question was sought. Table 5 shows the descriptive statistics. Out of 122 participating teachers, 79 were female and the rest were male.

TABLE 5.

THE DESCRIPTIVE STATISTICS OF THE FEMALE AND PARTICIPANTS

\begin{tabular}{|l|l|l|l|l|}
\hline \multirow{4}{*}{ Form } & Gender & Mean & Std. Deviation & N \\
\cline { 2 - 5 } & MALE & 2.1395 & .80420 & 43 \\
\cline { 2 - 5 } & FEMALE & 2.2278 & 1.03712 & 79 \\
\cline { 2 - 5 } & Total & 2.1967 & .95899 & 122 \\
\hline \multirow{4}{*}{ process } & MALE & 1.7674 & .71837 & 43 \\
\cline { 2 - 5 } & FEMALE & 1.4684 & .87465 & 79 \\
\cline { 2 - 5 } & Total & 1.5738 & .83238 & 122 \\
\hline \multirow{3}{*}{ social } & MALE & 1.0930 & .78115 & 43 \\
\cline { 2 - 5 } & FEMALE & 1.3165 & .95467 & 79 \\
\cline { 2 - 5 } & Total & 1.2377 & .90044 & 122 \\
\hline
\end{tabular}

Another test of between-subjects effects MANOVA was conducted this time to compare the responses of female and male participants. Table 6 shows the results.

TABLE 6.

THE RESULTS OF ANALYSIS OF VARIANCE OF THE FEMALE AND MALE RESPONSES

\begin{tabular}{|c|c|c|c|c|c|c|}
\hline Effect & & Value & $F$ & Hypothesis df & Error df & Sig. \\
\hline \multirow[t]{4}{*}{ Intercept } & Pillai's Trace & 1.000 & $1.121 \mathrm{E} 5$ & 3.000 & 118.000 & .000 \\
\hline & Wilks' Lambda & .000 & $1.121 \mathrm{E} 5$ & 3.000 & 118.000 & .000 \\
\hline & Hotelling's Trace & 2849.665 & $1.121 \mathrm{E} 5$ & 3.000 & 118.000 & .000 \\
\hline & $\begin{array}{l}\text { Roy's } \quad \text { Largest } \\
\text { Root }\end{array}$ & 2849.665 & $1.121 \mathrm{E} 5$ & 3.000 & 118.000 & .000 \\
\hline \multirow[t]{4}{*}{ gender } & Pillai's Trace & .036 & $1.454^{\mathrm{a}}$ & 3.000 & 118.000 & .231 \\
\hline & Wilks' Lambda & .964 & $1.454^{\mathrm{a}}$ & 3.000 & 118.000 & .231 \\
\hline & Hotelling's Trace & .037 & $1.454^{\mathrm{a}}$ & 3.000 & 118.000 & .231 \\
\hline & $\begin{array}{l}\text { Roy's } \\
\text { Root }\end{array}$ & .037 & $1.454^{\mathrm{a}}$ & 3.000 & 118.000 & .231 \\
\hline
\end{tabular}

a. Exact statistic

b. Design: Intercept + gender

The results of the analysis of variance show no significant difference between female and male responses to the questions addressing their view about writing, $\mathrm{F}(3,118)=1.454, \mathrm{p}=.231$.

The next step was to address teachers' belief based on a classification that assigns teachers to three classes (dominantoriented, dual-oriented, and multiple-oriented). To do this, the responses of the participants were analyzed by grouping the statements chosen by individual teachers according to the theoretical orientation the statements represent (formbased, process-based, and social-based). Teachers were considered to have a dominant orientation if they chose 4 or 5 statements related to one theoretical orientation. Teachers were considered to have a dual orientation if they chose 3 statements reflecting one orientation and 2 statements reflecting another orientation. Teachers who chose statements from all three orientations were considered to have a multiple orientation.

Table 7 demonstrates the results of the descriptive analysis of the participants' frequency for these three main effect groups. 
TABLE 7.

DESCRIPTIVE STATISTICS OF THE PARTICIPANTS' FREQUENCY BASED ON THEIR ORIENTATION

\begin{tabular}{|l|l|l|l|l|}
\hline & Frequency & Percent & Valid Percent & Cumulative Percent \\
\hline dominant orientation & 11 & 9.0 & 9.0 & 9.0 \\
\hline dual orientation & 38 & 31.1 & 31.1 & 40.2 \\
\hline multiple orientation & 73 & 59.8 & 59.8 & 100.0 \\
\hline Total & 122 & 100.0 & 100.0 & \\
\hline
\end{tabular}

According to this Table 11 participants were dominant-oriented, 38 were dual-oriented, and 73 participants were multiple-oriented.

The information about teachers' orientations was then compared with the teachers' sex, academic qualification, and experience and Chi-square was used to determine if there were any significant relationships between these background variables and teachers' beliefs.

We then examined if the number of years a teacher had been involved in teaching activities had a significant influence on her/his orientation class. Similar to the first section, we grouped the participating teachers into three: 1) those who had 2 years of teaching experience and less, 2) those who had between 2 to 8 years of teaching experience, and 3) those whose experience was 8 years and over. Table 8 shows the frequency and percentage of these groups.

TABLE 8.

DESCRIPTIVE STATISTICS OF THE PARTICIPANTS' FREQUENCY BASED ON THEIR EXPERIENCE

\begin{tabular}{|l|l|l|l|l|}
\hline & Frequency & Percent & Valid Percent & Cumulative Percent \\
\hline 2 and less & 30 & 24.6 & 24.6 & 24.6 \\
\hline $2-8$ & 76 & 62.3 & 62.3 & 86.9 \\
\hline 9 and over & 16 & 13.1 & 13.1 & 100.0 \\
\hline Total & 122 & 100.0 & 100.0 & \\
\hline
\end{tabular}

As can be seen from the above table, most of the participating teachers were involved in English teaching activities for 2 to 8 years (\%62.3), \%24.6 had been teaching English as a foreign language for less than 2 years, and only \%13.1 of them had had 8 years and over of experience.

In addition, Table 9 shows the percentages of teachers for each orientation who had different numbers of years of teaching experience.

TABLE 9.

DESCRIPTIVE STATISTICS OF TEACHERS' TEACHING EXPERIENCES AND ORIENTATIONS

\begin{tabular}{|c|c|c|c|c|c|}
\hline & & \multicolumn{3}{|c|}{ experience groups } & \multirow[t]{2}{*}{ Total } \\
\hline & & 2 and less & $2-8$ & 8 and over & \\
\hline \multirow{4}{*}{ dominant orientation } & Count & 2 & 7 & 2 & 11 \\
\hline & $\%$ within orientation & $18.2 \%$ & $63.6 \%$ & $18.2 \%$ & $100.0 \%$ \\
\hline & $\%$ within experience groups & $6.7 \%$ & $9.2 \%$ & $12.5 \%$ & $9.0 \%$ \\
\hline & $\%$ of Total & $1.6 \%$ & $5.7 \%$ & $1.6 \%$ & $9.0 \%$ \\
\hline \multirow{4}{*}{ dual orientation } & Count & 7 & 24 & 7 & 38 \\
\hline & $\%$ within orientation & $18.4 \%$ & $63.2 \%$ & $18.4 \%$ & $100.0 \%$ \\
\hline & $\%$ within experience groups & $23.3 \%$ & $31.6 \%$ & $43.8 \%$ & $31.1 \%$ \\
\hline & $\%$ of Total & $5.7 \%$ & $19.7 \%$ & $5.7 \%$ & $31.1 \%$ \\
\hline \multirow{4}{*}{ multiple orientation } & Count & 21 & 45 & 7 & 73 \\
\hline & $\%$ within orientation & $28.8 \%$ & $61.6 \%$ & $9.6 \%$ & $100.0 \%$ \\
\hline & $\%$ within experience groups & $70.0 \%$ & $59.2 \%$ & $43.8 \%$ & $59.8 \%$ \\
\hline & $\%$ of Total & $17.2 \%$ & $36.9 \%$ & $5.7 \%$ & $59.8 \%$ \\
\hline \multirow{4}{*}{ Total } & Count & 30 & 76 & 16 & 122 \\
\hline & $\%$ within orientation & $24.6 \%$ & $62.3 \%$ & $13.1 \%$ & $100.0 \%$ \\
\hline & $\%$ within experience groups & $100.0 \%$ & $100.0 \%$ & $100.0 \%$ & $100.0 \%$ \\
\hline & $\%$ of Total & $24.6 \%$ & $62.3 \%$ & $13.1 \%$ & $100.0 \%$ \\
\hline
\end{tabular}

Interestingly, these data reveal a similar trend across teachers who had teaching experiences of 2 years and less, 2-8 years, and 8 years and over. In fact, the majority of these teachers tended to be more dual or multiple oriented and only $\% 6.7$ of the first group, $\% 9.2$ of the second group, and \%12.5 of the third group were dominant oriented.

Now to examine the relationship between teaching experience of the participants and their orientation class, a ChiSquare test was conducted. Table 10 shows the results of the Chi-Square test.

TABLE 10.

CHI-SQUARE RESULTS FOR TEACHERS TEACHING EXPERIENCE AND ORIENTATION

\begin{tabular}{|l|l|l|l|}
\hline & Value & $\mathrm{df}$ & Asymp. Sig. (2-sided) \\
\hline Pearson Chi-Square & $3.026(\mathrm{a})$ & 4 & .554 \\
\hline Likelihood Ratio & 3.030 & 4 & .553 \\
\hline Linear-by-Linear Association & 2.462 & 1 & .117 \\
\hline N of Valid Cases & 122 & & \\
\hline
\end{tabular}


Based on the results demonstrated in Table 10 in analyzing the distribution according to the years of teaching experience, no significant difference was found, $\mathrm{X}^{2}(4, N=122)=3.026, p>.05$. Teaching experience seems to have no statistically significant influence on the orientation class of teachers.

Examining the relation between teachers' academic qualification and their orientation class comes next as shown in Table 11 and 12. Table11 shows the frequency and percentage of the teacher who held an MA or BA and Table 12 shows these statistical descriptions within different orientations.

TABLE 11.

DESCRIPTIVE STATISTICS OF THE PARTICIPANTS' FREQUENCY BASED ON THEIR QUALIFICATION.

\begin{tabular}{|l|l|l|l|l|}
\hline & Frequency & Percent & Valid Percent & Cumulative Percent \\
\hline MA & 74 & 60.7 & 60.7 & 60.7 \\
\hline BA & 48 & 39.3 & 39.3 & 100.0 \\
\hline Total & 122 & 100.0 & 100.0 & \\
\hline
\end{tabular}

TABLE 12.

DESCRIPTIVE STATISTICS OF TEACHERS' TEACHING EXPERIENCES AND THEORETICAL ORIENTATIONS

\begin{tabular}{|l|l|l|l|l|}
\hline \multirow{4}{*}{ dominant orientation } & & education & Total \\
\cline { 2 - 4 } & & MA & BA & \\
\hline \multirow{5}{*}{ dual orientation } & Count & 5 & 6 & 11 \\
\cline { 2 - 5 } & $\%$ within orientation & $45.5 \%$ & $54.5 \%$ & $100.0 \%$ \\
\cline { 2 - 5 } & $\%$ within education & $6.8 \%$ & $12.5 \%$ & $9.0 \%$ \\
\cline { 2 - 5 } & $\%$ of Total & $4.1 \%$ & $4.9 \%$ & $9.0 \%$ \\
\hline \multirow{5}{*}{ multiple orientation } & Count & 21 & 17 & 38 \\
\cline { 2 - 5 } & $\%$ within orientation & $55.3 \%$ & $44.7 \%$ & $100.0 \%$ \\
\cline { 2 - 5 } & $\%$ within education & $28.4 \%$ & $35.4 \%$ & $31.1 \%$ \\
\cline { 2 - 5 } & $\%$ of Total & $17.2 \%$ & $13.9 \%$ & $31.1 \%$ \\
\hline \multirow{5}{*}{ Total } & Count & 48 & 25 & 73 \\
\cline { 2 - 5 } & $\%$ within orientation & $65.8 \%$ & $34.2 \%$ & $100.0 \%$ \\
\cline { 2 - 5 } & $\%$ within education & $64.9 \%$ & $52.1 \%$ & $59.8 \%$ \\
\cline { 2 - 5 } & $\%$ of Total & $39.3 \%$ & $20.5 \%$ & $59.8 \%$ \\
\hline & Count & 74 & 48 & 122 \\
\cline { 2 - 5 } & $\%$ within orientation & $60.7 \%$ & $39.3 \%$ & $100.0 \%$ \\
\cline { 2 - 5 } & $\%$ within education & $100.0 \%$ & $100.0 \%$ & $100.0 \%$ \\
\cline { 2 - 5 } & $\%$ of Total & $60.7 \%$ & $39.3 \%$ & $100.0 \%$ \\
\hline
\end{tabular}

Table 11 shows that 60.7 percentage of the participants held a master's degree and the rest had a bachelor's degree. As we look at Table 12, we see that here again a trend similar to what we saw in the previous section is leading. Both groups of teachers tend to be more dual or multiple oriented and only 6.8 percent of the master's degree holders and 12.5 percent of bachelor's degree holders seemed to follow one dominant theoretical orientation.

Now to examine the relation between academic qualification and orientation class a Chi-Square test of independence was performed. Table 13 reveals the results of this analysis.

TABLE 13.

CHI-SQUARE RESULTS FOR TEACHERS TEACHING EXPERIENCE AND THEORETICAL ORIENTATION

\begin{tabular}{|l|l|l|l|}
\hline & Value & df & Asymp. Sig. (2-sided) \\
\hline Pearson Chi-Square & $2.323(\mathrm{a})$ & 2 & .313 \\
\hline Likelihood Ratio & 2.301 & 2 & .317 \\
\hline $\begin{array}{l}\text { Linear-by-Linear } \\
\text { Association }\end{array}$ & 2.303 & 1 & .129 \\
\hline N of Valid Cases & 122 & & \\
\hline
\end{tabular}

The results of the Chi-Square test show that the relation between these variables was not significant, $\mathrm{X}^{2}(2, N=122)$ $=2.323, p>.05$. Therefore, similar to teaching experience, academic qualification seems to have no statistically significant influence on the teachers' orientation class.

The relation between the variable of sex and teachers' orientation class was also investigated. Similar to the pervious sections first the descriptive statistics of the participants is presented in Tables 14 and 15.

TABLE 14.

DESCRIPTIVE STATISTICS OF THE PARTICIPANTS' FREQUENCY BASED ON THEIR SEX

\begin{tabular}{|l|l|l|l|l|l|}
\hline \multicolumn{2}{|c|}{} & Frequency & Percent & Valid Percent & Cumulative Percent \\
\hline \multirow{3}{*}{ Valid } & male & 43 & 35.2 & 35.2 & 35.2 \\
\cline { 2 - 6 } & female & 79 & 64.8 & 64.8 & 100.0 \\
\cline { 2 - 6 } & Total & 122 & 100.0 & 100.0 & \\
\hline
\end{tabular}


TABLE 15.

\begin{tabular}{|c|c|c|c|c|}
\hline & & \multicolumn{2}{|l|}{ sex } & \multirow[t]{2}{*}{ Total } \\
\hline & & male & female & \\
\hline \multirow{4}{*}{ dominant orientation } & Count & 3 & 8 & 11 \\
\hline & $\%$ within orientation & $27.3 \%$ & $72.7 \%$ & $100.0 \%$ \\
\hline & $\%$ within sex & $7.0 \%$ & $10.1 \%$ & $9.0 \%$ \\
\hline & $\%$ of Total & $2.5 \%$ & $6.6 \%$ & $9.0 \%$ \\
\hline \multirow{4}{*}{ dual orientation } & Count & 11 & 27 & 38 \\
\hline & $\%$ within orientation & $28.9 \%$ & $71.1 \%$ & $100.0 \%$ \\
\hline & $\%$ within sex & $25.6 \%$ & $34.2 \%$ & $31.1 \%$ \\
\hline & $\%$ of Total & $9.0 \%$ & $22.1 \%$ & $31.1 \%$ \\
\hline \multirow{4}{*}{ multiple orientation } & Count & 29 & 44 & 73 \\
\hline & $\%$ within orientation & $39.7 \%$ & $60.3 \%$ & $100.0 \%$ \\
\hline & $\%$ within sex & $67.4 \%$ & $55.7 \%$ & $59.8 \%$ \\
\hline & $\%$ of Total & $23.8 \%$ & $36.1 \%$ & $59.8 \%$ \\
\hline \multirow[t]{4}{*}{ Total } & Count & 43 & 79 & 122 \\
\hline & $\%$ within orientation & $35.2 \%$ & $64.8 \%$ & $100.0 \%$ \\
\hline & $\%$ within sex & $100.0 \%$ & $100.0 \%$ & $100.0 \%$ \\
\hline & $\%$ of Total & $35.2 \%$ & $64.8 \%$ & $100.0 \%$ \\
\hline
\end{tabular}

A chi-square test of independence was run to examine the orientation classes of the participants according to their sex. Table 16 reveals the results.

TABLE 16.

CHI-SQUARE RESULTS FOR TEACHERS' SEX AND THEORETICAL ORIENTATION

\begin{tabular}{|l|l|l|l|}
\hline & Value & df & Asymp. Sig. (2-sided) \\
\hline Pearson Chi-Square & $1.609(\mathrm{a})$ & 2 & .447 \\
\hline Likelihood Ratio & 1.631 & 2 & .442 \\
\hline Linear-by-Linear Association & 1.424 & 1 & .233 \\
\hline N of Valid Cases & 122 & & \\
\hline
\end{tabular}

Table 16 shows that the relation between these teachers' sex and their orientation class was statistically insignificant, $\mathrm{X}^{2}(2, N=122)=1.609, p>.05$. Both female and male teachers were likely to belong to similar orientations classes in teaching writing in an EFL class. These results are no different than the results of the analysis of the variables teaching experience and academic qualification.

The open-ended question collected in the final part of the survey included some impressions and suggestions made by the participating teachers. This part reflects the beliefs of the participants about the skill of writing and its teaching which is based on a qualitative approach. More precisely, the question is divided into two parts, the first part asks about the teachers' beliefs about writing skill and its importance, and the second part concerns about their beliefs about the way writing should be taught. Totally 122 teachers return the questionnaire but only 71 of them answered this question. These answers were analyzed and the most common patterns and beliefs were taken out and reported in the following sections.

In the first part, the participants were asked about their belief about writing skill and its importance. They mainly expressed similar ideas. Most teachers considered it as a productive skill the same as speaking. They believed that writing is a kind of skill whose learning and teaching provide serious problems for learners and teachers. A lot of teachers believed that writing is just as important as other language skills, but in our country, Iran, it is mostly ignored and is not practiced the as sufficiently as other language skills. Their reason for that is that writing needs a lot of time and thought and there is not enough time for teaching and practicing writing in the classes so it is considered just as a homework assignment. Majority of the participants believed that language learners are reluctant to learn writing and they find it boring and uninteresting.

The second part of the question sought answers to how participants would teach writing. Firstly, the proverb "practice makes perfect" is widely believed by the participating teachers; they said that writing is best learned by doing a lot of writing.

A few teachers believed that brainstorming before starting to write is necessary. A few of them talk about the content of text and its importance. They believed that the subjects for writing should be interesting and teachers should be careful about choosing a suitable subject.

Most teachers suggested that using different samples to work on and analyze is one of the best ways of teaching writing skills. They claimed that working on a sample, analyzing sentences such as finding the topic sentence and supporting ideas and thesis statement could be helpful.

Some teachers are concerned about the cohesion and coherence of the texts; they believed that a person who can write a text which is both coherent and cohesive knows writing skill well. This can be fitted in a wider picture which is believed by a lot of participants in this study; according to them a focus on the organization of paragraphs and ideas is an effective way of teaching and learning writing. Contrary to the majority of the participants, some teachers believed 
that students should be taught to write a good sentence first, then a good paragraph, and only after that to write an essay. They believed that knowing grammatical structures and vocabulary plays an important role in learning writing skills.

\section{DISCUSSION}

The results suggest that many teachers believe in a form-based patterning in writing, though insignificantly. Others of course selected a process-based view and social-based view on writing. In addition, this manner was not affected by the teachers' academic qualification, years of experience, or gender. Also based on teachers' responses, the factors of experience, academic qualification, and gender are not effective for placing teachers in different classes of theoretical orientation (dominant oriented, dual oriented and multiple oriented). These findings are not in line with Lockhart (2008), Tsui (2003), Ghodousi (2008), and Richards (1996), whose findings indicated differences in teacher's beliefs resulting from above-mentioned variables.

While the results show that there is no significant difference between the beliefs of teachers with master's degree and the beliefs of teachers with bachelor's degree, Lockhart's (2008) reports that teachers' beliefs about writing skill differed according to their academic qualification in Hong Kong; teachers with post-graduate qualification hold different beliefs toward writing from teachers with lower professional qualifications. Teachers who have undertaken post-graduate study are more likely to adopt a social or process orientation while teachers who have only completed a bachelor's degree are more likely to hold form-oriented beliefs.

The situation is partly the same for the factor of experience. While Richards (1996) states that teachers' experience of work is one of the sources of change for language teachers' belief system, this study suggests that less experienced teachers have the same beliefs as more experienced teachers toward writing skills and its teaching. It means that there is no difference between less experienced teachers' belief and more experienced teachers' beliefs. This is in line with Lockhart (2008) which shows no significant difference between teachers' beliefs according to years of teaching experience in Hong Kong. Contrary to these findings Tsui (2003) says teachers' beliefs may be changed or modified as teachers gain experience or as they encounter critical incidents that challenge them. They may also be very resistant to change.

Also, comparison of male and female teachers' beliefs about writing and its teaching shows no significant difference between them. They were considered to have the same orientations. In the study of teachers' beliefs about grammar and its teaching by Ghodousi (2008) male teachers had stronger beliefs than women toward some techniques of teaching.

Interestingly, the quantitative results matched the qualitative ones.Results of the open-ended question show that teachers mostly apply form-based views toward teaching and learning writing. The findings reported here are somewhat consistent with those of studies in Hong Kong, which indicated that Hong Kong teachers had a strong preference for focusing on grammar (e.g., Hirvela\& Law, 1991; Richards, Tung, \& Ng, 1991). A form-based orientation to writing leads to constraints which include specifying the number of essays students are to write during the year, requiring teachers to correct every grammatical mistake students make when writing, specifying how much class time can be allotted to writing lessons, and requiring students to practice writing under examination conditions.

\section{CONCLUSION}

Based on the findings of this study, experience, academic qualification, and gender do not affect Iranian teachers' beliefs about writing and its teaching. This suggests that there seems to be other factors affecting Iranian teachers' belief about writing that were not studied in this research and, therefore, need to be considered by further research. Other factors such as student-related factors, cultural context of school, and educational curriculums may affect teachers' beliefs. Theories of teacher development propose that changes in teacher's classroom practices is a gradual process which begins with changes in attitudes and beliefs (Freeman, 1989). In the early stages of the innovation process, teachers first acknowledge new ideas and form an attitude toward them (Rogers, 1983). If a decision is made to adopt the innovation, teachers usually implemented the innovation "on a limited basis, modifying it as needed to fit the conditions of their individual situations" (Pennington, 1996, p.322). At a later stage, teachers will either confirm or reverse their earlier decision about the innovation.

\section{REFERENCES}

[1] Burns, A. (1992). Staring all over again: From teaching adults to teaching beginners. In D. Freeman \& J. C Reichards (Eds.), Teacher learning in language teaching (p.154-177). Cambridge: Cambridge University Press.

[2] Connelly, F. M., \& Clandinin, D. J. (1988). Teachers as curriculum planners: Narratives of experience. New York: Teachers College Press.

[3] Elbaz, F. (1981). The teacher's "practical knowledge": A report of a case study. Curriculum Inquiry, 11, 43-71.

[4] Fogarty, J. L., Wang, M. C. \& Creek, R. (1983). A descriptive study of experienced and novice teachers' interactive instructional thoughts and actions. Journal of Educational Research, 77(1), 22-32.

[5] Freeman, D. (1989). Teacher training, development, and decision making: A model of teaching and related strategies for language teacher education. TESOL Quarterly, 23 (1), 27-45.

[6] Gere, A. R. (1987). Writing Groups: History Theory, and Implications. Carbondale: IL Southern Illinois University Press. 
[7] Ghodousi, T. (2008). Exploring Language Teachers Beliefs and Its Relationship With Grammar Teaching. Unpublished Master's thesis, University of Najafabad, Iran.

[8] Hirvela, A., \& Law, E. (1991). A survey of local English teachers' attitudes toward English and ELT. Institute of Language in Education Journal, 8, 25-38.

[9] Hollingsworth, S. (1989). Prior beliefs and cognitive change in learning to teach. American Educational Research Journal, 26 , 161-189.

[10] Johnson, K. E. (1992). The relationship between teachers' beliefs and practices during literacy instruction for non-native speakers of English. Journal of Reading Behavior, 24, 83-108.

[11] Kagan, D. M. \& Tippins, D. J. (1991). How teachers' classroom cases express their pedagogical beliefs. Journal of Teacher Education, 42, 281-291.

[12] Leinhardt, G. (1990). Capturing craft knowledge in teaching. Educational Researcher, 19(2), 18-25.

[13] Lockhart, Ch. (2008). Teachers' Beliefs about Writing in Hong Kong Secondary Schools. Retrieved June 13, 2011, from: http://sunzi.lib.hku.hk/hkjo/view/10/1000107.

[14] Magliaro, S.G. \& Borko, H. (1986). A naturalistic investigation of experienced teachers' and student teachers' instructional practices. Teaching and Teacher Education, 2, 127-137.

[15] Pajares, M. (1992). Teachers' beliefs and educational research. Clearing up a messy construct. Review of Educational Research, $62(3), 307-332$.

[16] Pennington, M. (1996). When input becomes intake: Tracing the sources of teachers' attitude change. In D. Freeman and J.C. Richards (Eds.). Teacher Learning in Language Teaching. (pp. 320-348). New York: Cambridge University Press.

[17] Peterson, P. L. \& Comeaux, M. A. (1987). Teachers' schemata for classroom events: The mental scaffolding of teachers' thinking during classroom instruction. Teaching and Teacher Education, 3, 319-331.

[18] Richards, J. C. (1996). Teachers' maxims in language teaching. TESOL Quarterly, 30, 281-296.

[19] Richards, J.C., Tung, P. \& Ng P. (1992). The culture of the English language teacher: A Hong Kong example. RELC journal, $23,81-102$.

[20] Rogers, E. M. (1983). Diffusion of Innovations. New York: Free Press.

[21] Shavelson, R. J. \& Stern, P. (1981). Research on teachers' pedagogical thoughts, judgments, decisions, and behavior. Review of Educational Research, 51, 455-498.

[22] Shulman, L. S. (1987). Knowledge and teaching: Foundations of the new reform. Harvard Educational Review, 57(1), 1-22.

[23] Silva, T. (1990). Second language composition instruction: Developments, issues, and directions in ESL. In B. Kroil (Ed.). Second Language Writing: Research insights for the classroom. Cambridge: CUP.

[24] Thompson, A. G. (1992). Teachers' beliefs and conceptions: A synthesis of the research. In D. A. Grouws (Ed.), Handbook of research on mathematics teaching and learning (pp. 127-146). New York: Macmillan.

[25] Tribble, C. (1996). Writing. Oxford: Oxford University Press.

[26] Tsui, A. (1996). Learning how to teach ESL writing. In D. Freeman and J.C. Richards (Eds.).Teacher Learning in Language Teaching (pp.97-119). New York: Cambridge University Press.

[27] Williams, M. \& Burden, R. (1997). Psychology for language teachers. Cambridge: Cambridge University Press.

Bita Khanalizadeh has an MA in TEFL. She received her MA from Islamic Azad University, Najafabad Branch in 2011. Her major interest is Second Language Acquisition and cognition.

Hamid Allami is assistant professor in Applied Linguistics. He has published many articles in both local and international scholarly journals. His main interests are Discourse analysis, Pragmatics and Interlanguage Pragmatics. 